MALLOMO: Journal of Community Service

https://jurnal.umsrappang.ac.id/mallomo/index

Vol 1, No 1, Desember 2020, pp 30-34

\title{
Optimalisasi Karang Taruna dalam Pengembangan Potensi Generasi Muda di Desa Tuncung
}

\author{
Pratiwi Ramlan \\ Administrasi Publik, Universitas Muhammadiyah Sidenreng Rappang \\ Email: pratiwiramlan@yahoo.com
}

Abstract. The young generation is a part of the world's population that is very potential and has a very large contribution to the future development of the world. But the social problems experienced by the younger generation at this time remain a problem that is never endlessly discussed. Especially the problem of unemployment, juvenile delinquency and dropping out of school. The development of the quality of the younger generation is not only done through formal education, but can be done through institutions (institutions or organizations) that are committed to the development of the young generation. The role of youth organizations as a component of community social participation needs to be improved and developed. In line with this, local organizations as potential resources are required to play an optimal role in mobilizing the community in development. Local organizations in the village are a place to meet needs or solve community problems. One of the local organizations in almost every village or kelurahan in Indonesia is Youth Organization as a place or place for youth development.

\begin{abstract}
Abstrak. Generasi muda adalah bagian dari penduduk dunia yang sangat potensial dan memiliki sumbangan teramat besar bagi perkembangan masa depan dunia. Namun permasalahan sosial yang dialami generasi muda pada saat ini tetap menjadi permasalahan yang tidak pernah habis-habisnya dibicarakan. Terutama permasalahan pengangguran, kenakalan remaja dan putus sekolah. Pengembangan kualitas generasi muda tidak hanya dilakukan melalui pendidikan formal, tetapi dapat dilakukan melalui wadah (lembaga atau organisasi) yang mempunyai komitmen terhadap pengembangan generasi muda tersebut. Peran serta organisasi kepemudaan tersebut sebagai salah satu komponen partisipasi sosial masyarakat perlu ditingkatkan dan dikembangkan. Sejalan dengan hal tersebut, organisasi lokal sebagai sumber daya potensial dituntut untuk berperan secara optimal untuk menggerakan masyarakat dalam pembangunan. Organisasi lokal di lingkungan desa/kelurahan merupakan wadah untuk memenuhi kebutuhan ataupun memecahkan permasalahan masyarakat. Salah satu organisasi lokal yang ada di hampir setiap desa atau kelurahan
\end{abstract}


di Indonesia adalah Karang Taruna sebagai tempat atau wadah pembinaan generasi muda. Pada awalnya Karang Taruna merupakan organisasi bentukan pemerintah, namun dalam perkembangannya kini Karang Taruna banyak muncul dengan ide, gagasan dan aspirasi masyarakat.

Keywords:

Young Generation,

Village Potential, Youth

Organization

Kata Kunci:

Generasi Muda, Potensi

desa, Karang Taruna
Coresponden author:

Email: pratiwiramlan@yahoo.com

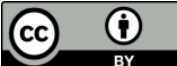

artikel dengan akses terbuka di bawah lisensi CC BY -4.0

\section{PENDAHULUAN}

Kehidupan masyarakat yang maju, timbul banyak kebutuhan akan pelayanan umum bagi kelangsungan hidup masyarakat sebagai kelompok, maupun sebagai perseorangan. Karang Taruna sebagai lembaga kemasyarakatan desa yang tidak hanya sebagai kumpulan remaja-remaja yang mempunyai misi dan tujuan, namun dapat membantu warga atau masyarakat sekitar yang keadaannya tidak menguntungkan. Karang Taruna merupakan salah satu organisasi sosial kemasyarakatan yang diakui keberadaannya dalam penyelenggaraan kesejahteraan sosial sebagaimana tercantum dalam Pasal 38 ayat (1-3), Bab VII tentang Peran Masyarakat UndangUndang Nomor 11 Tahun 2009 tentang Kesejahteraan Sosial,ayat (1) masyarakat mempunyai kesempatan yang seluas-luasnya untuk berperan dalam penyelenggaraan kesejahteraan sosial, ayat (2) peran sebagaimana dimaksud pada ayat (1) dapat dilakukan oleh perseorangan, keluarga, organisasi keagamaan, organisasi sosial kemasyarakatan, lembaga swadaya masyarakat, organisasi profesi, badan usaha, lembaga kesejahteraan sosial dan lembaga kesejahteraan sosial asing, ayat (3) peran sebagaimana dimaksud pada ayat (2) dilakukan untuk mendukung keberhasilan penyelenggaraan kesejahteraan sosial.

Demi mencapai tujuan nasional tersebut dilaksanakan berbagai upaya pembangunan dan pemberdayaan disegala bidang, baik sumber daya alam maupun sumber daya manusianya. Salah satu sumber daya yang sering menjadi permasalahan yaitu sumber daya manusia, yang berhubungan erat dengan kualitas manusia yang pada dasarnya sumber daya manusia itu adalah bagian dan generasi muda. Karena generasi muda inilah yang akan kelak meneruskan tongkat estafet kepemimpinan dimasa yang akan datang, sehingga kita membutuhkan generasi yang terampil, berakhlak, bermoral serta cinta tanah air dan dapat diandalkan di tengah masyarakat terutama bangsa dan negara. Peranan generasi muda sebagai pilar,penggerak, dan pengawal jalannya reformasi dan pembangunan sangat diharapkan. Generasi muda adalah remaja yang nantinya akan menjadi tunas harapan dan modal pembangunan bangsa yang akan datang. (Damayanty, 2012:3). Menurut Syukur (2008:27) generasi muda atau pemuda adalah penduduk yang berusia 15-35 tahun, yaitu mereka yang diidealkan sebagai sosok yang penuh energi, semangat, dan kreativitas untuk menciptakan semangat pembaharuan. Namun permasalahan yang dihadapi generasi muda yang dapat menghambat pertumbuhan dan perkembangan dirinya menyebutkan ada sembilan hal yaitu sebagai berikut (Direktorat Kesejahteraan Anak dan Remaja 1978 :37) :

1. Kekurangpastian generasi muda dihari depan

2. Tidak seimbangnya jumlah anak dan remaja/generasi muda dengan fasilitas pendidikan yang tersedia

3. Cukup besarnya jumlah anak dan remaja yang berhenti sekolah dan anak/remaja yang tidak sekolah 


\section{4 | MALLOMO: Journal of Community Service}

4. Kekurangan/terbatasnya lapangan pekerjaan yang tersedia bagi pemuda/pemudi dan jumlah pengangguran dikalangan generasi muda yang semakin mengkhawatirkan

5. Kekurangan gizi yang diperlukan bagi pertumbuhan dan perkembangan anak

6. Perkawinan dibawah umur yang masih banyak dilakukan oleh golongan-golongan masyarakat terutama masyarakat pedesaan;

7. Adanya generasi muda yang menderita fisik dan mental social

8. Keberandalan dan kenakalan remaja,

9. Penyalahgunaan narkotika dikalangan muda-mudi

Melihat permasalahan yang dihadapi generasi muda tersebut, maka perlu adanya suatu usaha yang nantinya akan dapat membantu generasi muda ymg bermasalah ini dalam memecahkan masalahnya, yang mana usaha tersebut memerlukan suatu wadah untuk membina dan mengarahkan generasi muda tersebut, pelaksanaan pembinaan tersebut merupakan tugas dan kewajiban aparat pelaksana baik dari tingkat pusat maupun daerah yang sesuai dengan bidangnya, yang diterjemahkan ketengah masyarakat terutama dalam pemberian bantuan dan bimbingan yaitu dengan membentuk suatu organisasi yang nantinya akan menjadi wadah pernbinaan generasi muda tersebut terkhususnya di pedesaan.

Salah satu organisasi kemasyarakatan yang menampung aspirasi dan melibatkan generasi muda adalah Karang Taruna. Selain menampung aspirasi, Karang Taruna juga berperan sebagai wadah penanaman rasa kebangsaan secara nasional, pengembangan potensi diri dan merupakan organisasi yang bergerak dalam bidang kesejahteraan sosial.

Karang Taruna adalah organisasi kepemudaan di Indonesia. Karang Taruna merupakan wadah pengembangan generasi muda nonpartisan, yang tumbuh atas dasar kesadaran dan rasa tanggung jawab sosial dari, oleh dan untuk masyarakat khususnya generasi muda di wilayah Desa / Kelurahan atau komunitas sosial sederajat, yang terutama bergerak dibidang kesejahteraan sosial. Sebagai organisasi sosial kepemudaan Karang Taruna merupakan wadah pembinaan dan pengembangan serta pemberdayaan dalam upaya mengembangkan kegiatan ekonomis produktif dengan pendayagunaan semua potensi yang tersedia dilingkungan baik sumber daya manusia maupun sumber daya alam yang telah ada. Sebagai organisasi kepemudaan, Karang Taruna berpedoman pada Pedoman Dasar dan Pedoman Rumah Tangga dimana telah pula diatur tentang struktur penggurus dan masa jabatan dimasing-masing wilayah mulai dari Desa / Kelurahan sampai pada tingkat Nasional. Semua ini wujud dari pada regenerasi organisasi demi kelanjutan organisasi serta pembinaan anggota Karang Taruna baik dimasa sekarang maupun masa yang akan datang.

Keberadaan karang taruna dimaksudkan sebagai wadah untuk menampung aspirasi masyarakat, khususnya generasi muda dalam rangka mewujudkan rasa kesadaran dan kepedulian sosial terhadap masyarakat pada umumnya. Tujuannya tidak lain adalah terwujudnya kesejahteraan sosial yang semakin meningkat bagi generasi muda. Untuk mencapai sasaran tersebut, tugas pokok karang taruna adalah tercantum adalam Peraturan Mentri Sosial RI No.83/HUK/2005 adalah organisasi sosial wadah pembinaan dan pengembangan generasi muda yang tumbuh dan berkembang atas dasar kesadaran dan kepedulian sosial dari, oleh, dan untuk masyarakat terutama generasi muda di wilayah desa/kelurahan atau komunitas sederajat dan terutama bergerak di bidang usaha kesejahteraan social. Pemuda bersama-sama dengan pemerintah dan komponen masyarakat lainnya untuk menanggulangi berbagai masalah kesejahteraan dan kepedulian sosial terutama yang dihadapi generasi muda, baik yang bersifat preventif, rehabilitative, maupun pengembangan potensi generasi muda di lingkungannya.

Sejalan dengan perkembangan Karang Taruna yang mampu memberikan peran dan kontribusi dalam pembangunan di wilayah,Karang Taruna memiliki landasan hukum yang memperkuat keberadaannya di masyarakat, yaitu:

- Keputusan Menteri Sosial RI Nomor 13/HUK/KEP/1981 tentang Susunan Oganisasi dan Tata Kerja Karang Taruna;

- Ketetapan MPR Nomor II/MPR/1983 yang menetapkan Karang Taruna sebagai salah satu wadah pengembangan generasi muda, disamping OSIS, KNPI, Pramuka, dan lain - lain; 
- Keputusan Menteri Sosial RI Nomor 77/HUK/2010 tentang Pedoman Dasar Karang Taruna. Tujuan Karang Taruna adalah :

a. Terwujudnya pertumbuhan dan perkembangan kesadaran dan tanggung jawab sosial setiap generasi muda warga Karang Taruna dalam mencegah, menagkal, menanggulangi dan mengantisipasi berbagai masalah sosial.

b. Terbentuknya jiwa dan semangat kejuangan generasi muda warga Karang Taruna yang Trampil dan berkepribadian serta berpengetahuan.

c. Tumbuhnya potensi dan kemampuan generasi muda dalam rangka mengembangkan keberdayaan warga Karang Taruna.

d. Termotivasinya setiap generasi muda warga Karang Taruna untuk mampu menjalin toleransi dan menjadi perekat persatuan dalam keberagaman kehidupan bermasyarakat, berbangsa dan bernegara.

e. Terjalinnya kerjasama antara generasi muda warga Karang Taruna dalam rangka mewujudkan taraf kesejahteraan sosial bagi masyarakat.

f. Terwujudnya Kesejahteraan Sosial yang semakin meningkat bagi generasi muda di desa/kelurahan atau komunitas adat sederajat yang memungkinkan pelaksanaan fungsi sosialnya sebagai manusia pembangunan yang mampu mengatasi masalah kesejahteraan sosial dilingkungannya.

g. Terwujudnya pembangunan kesejahteraan sosial generasi muda di desa/kelurahan atau komunitas adat sederajat yang dilaksanakan secara komprehensif, terpadu dan terarah serta berkesinambungan oleh Karang Taruna bersama pemerintah dan komponen masyarakat lainnya.

Metode dalam penerapan program ini disusun secara sistematis, yang bertujuan untuk memaksimalkan jalannya program. Susunan pelaksanaan kegiatan dapat dipahami melalui matriks berikut ini:

\begin{tabular}{|c|l|l|}
\hline No & \multicolumn{1}{|c|}{ Jenis Kegiatan } & \multicolumn{1}{c|}{ Tujuan } \\
\hline 1 & Observasi & $\begin{array}{l}\text { Memperoleh data up to date terkait proses dan } \\
\text { kondisi serta permasalahan yang dihadapi oleh } \\
\text { lembaga Karng Taruna Desa Tuncung Kecamatan } \\
\text { Maiwa. Salah satu kegiatan yang dilaksanakan } \\
\text { disini yaitu melakukan pertemuan dengan } \\
\text { pengurus Karang Taruna dengan muatan } \\
\text { membahas masalah penyebab tidak aktifnya } \\
\text { lembaga karang taruna di desa Tuncung. }\end{array}$ \\
\hline 2 & Perencanaan & $\begin{array}{l}\text { Membuat perencanaan program yang cocok } \\
\text { untuk menyelesaikan permasalahan yang } \\
\text { dihadapi. Masalah yang dimaksud adalah } \\
\text { kesimpulan dari hasil observasi dan diskusi } \\
\text { bersama pihak pengurus. }\end{array}$ \\
\hline 3 & Pemetaan & $\begin{array}{l}\text { Tahapan ini bertujuan untuk memberikan } \\
\text { kejelasan kepada masing-masing pihak yang } \\
\text { terlibat di dalamnya }\end{array}$ \\
\hline 4 & Pelaksanaan & $\begin{array}{l}\text { Melakukan penyuluahan tentang fungsi Karang } \\
\text { Taruna di Desa Tuncung agar dapat berperan } \\
\text { dalam pengembangan generasi muda. }\end{array}$ \\
\hline 5 & Tindak Lanjut & $\begin{array}{l}\text { Menyusun program - progam sebagai tindak } \\
\text { lanjut setelah melihat perkembangan dan hasil } \\
\text { evaluasi dalam pengaktifan kembali lembaga } \\
\text { Karang Taruna di Desa Tuncung Kecamatan } \\
\text { Maiwa. }\end{array}$ \\
\hline
\end{tabular}




\section{Metode}

Metode yang digunakan dalam kegiatan pengabdian masyarakat ini adalah pendekatan kualitatif. Pendekatan kualitatif merupakan metode-metode untuk mengeksplorasi dan memahami makna yang oleh sejumlah individu atau sekelompok orang dianggap berasal dari masalah sosial atau kemanusiaan. Proses penelitian kualitatif ini melibatkan upaya-upaya penting, seperti mengajukan pertanyaan-pertanyaan dan prosedur-prosedur, mengumpulkan data yang spesifik dari para partisipan , menganalisis data secara indukif mulai dari tema-tema yang khusus ke tema-tema umum, dan menafsirkan makna data (Ahmad, 2015;52). Bogdan dan Taylor (Maleong, 2007:4) mendefenisikan metodologi kualitatif sebagai prosedur penelitian yang menghasilkan data deskriptif berupa kata-kata tertulis atau lisan dari orang-orang dan perilaku yang dapat diamati. Pendekatan ini diarahkan pada latar dari individu tersebut secara holistik(utuh). Dalamhal ini tidak boleh mengisolasikan individu atau organisasi ke dalam variabel atau hipotesis, tapi perlu memandangnya sebagai bagian dari suatu keutuhan.

Metode kegiatan yang dilakukan dalam pengabdian masyarakat ini adalah: kegiatan pengabdian masayarakat dilakukan dengan pendekatan workshop, meliputi: ceramah, tanya jawab, pelatihan, diskusi, pendampingan. Adapun proses penyelenggaraannya meliputi:

Tahap I

Peserta diberikan ceramah terkait eksistensi pemuda dalam memberikan kontribusi pada pembangunan desanya, pentingnya berkarya serta diberikan motivasi agar mereka mau berpartisipasi dalam membangun. Dalam pemberian ceramah, para peserta diberi kesempatan untuk bertanya mengenai kondisi realitas yang dialami pada organisasi yang sudah berjalan.

Tahap II

Para peserta diberi pemahaman fungsi dan peran pemuda, pemahaman pentingnya membuat kegiatan dalam rangka membangun desanya.

Tahap III

Memberikan kesempatan pada peserta untuk mendiskusikan rencana kegiatan yang akan di lakukan untuk mengaktifkan organisasi Karang Taruna.

\section{Hasil Dan Pembahasan}

Karang Taruna adalah Organisasi Sosial wadah pengembangan generasi muda yang tumbuh dan berkembang atas dasar kesadaran dan tanggung jawab sosial dari, oleh dan untuk masyarakat terutama generasi muda di wilayah desa/ kelurahan dan terutama bergerak di bidang usaha kesejahteraan sosial.

Karang Taruna adalah suatu organisasi sosial, perkumpulan sosial yang dibentuk oleh masyarakat yang berfungsi sebagai sarana partisipasi masyarakat dalam melaksanakan Usaha Kesejahteraan Sosial (UKS).Sebagai wadah pengembangan generasi muda, Karang Taruna merupakan tempat diselenggarakannya berbagai upaya atau kegiatan untuk meningkatkan dan mengembangkan cipta, rasa, karsa, dan karya generasi muda dalam rangka pengembangan sumber daya manusia (SDM).

Karang Taruna tumbuh dan berkembang atas dasar adanya kesadaran terhadap keadaan dan permasalahan di lingkungannya serta adanya tanggung jawab sosial untuk turut berusaha menanganinya.Kesadaran dan tanggung jawab sosial tersebut merupakan modal dasar tumbuh dan berkembangnya Karang Taruna.

Karang Taruna tumbuh dan berkembang dari generasi muda, diurus atau dikelola oleh generasi muda dan untuk kepentingan generasi muda dan masyarakat di wilayah desa/kelurahan atau komunitas adat sederajat.Karenanya setiap desa/kelurahan atau komunitas adat sederajat dapat menumbuhkan dan mengembangkan Karang Tarunanya sendiri.

Gerakannya di bidang Usaha Kesejahteraan Sosial berarti bahwa semua upaya program dan kegiatan yang diselenggarakan Karang Taruna ditujukan guna mewujudkan kesejahteraan sosial masyarakat terutama generasi mudanya.Mencermati hal tersebut bahwa Kuliah Kerja lapang Plus ( KKLP )suatu 
bentuk kewajiban mahasiswa dalam mengabdi di masyarakat selama 2 bulan dan mengaplikasiskan teori-teori yang di pelajari di kampus Stisip Muhammadiyah Rappang.

Di dalam pelaksanaan Kuliah Kerja Lapang Plus ( KKLP ) Pada awalnya mahasiswa melakukan salah satu tahap yang di maksud observasi. Dimana Observasi adalah proses mahasiswa melakukan pengenalan lingkungan serta terjun langsung ke masyarakat meihat kondisi dan potensi yang ada di desa.Salah satu potensi desa yang di temukan dalam observasi yaitu mayoritas anak muda desa Tuncung aktif di bidang olahraga tetapi tidak memiliki wadah yang bisa mendukung bakat mereka. Olehnya itu di butuhkan sentimen sentimen agar anak muda desa Tuncung dapat mengefresikan bakat mereka tanpa terkendala ,misalnya berpatokan dari minat dan bakat anak muda desa Tuncung dalam bidang olahraga. Olehnya itu anak muda desa Tuncung sangat memerlukan wadah yang bisa menampung minat dan bakat mereka.

Selama tiga hari melakukan observasi peluang dan potensi yang kami temukan menjadi titik acuan salah satu program kerja yang di rancang KKLP posko desa Tuncung yaitu bahwa mahasiswa hadir untuk mencarikan solusi dan bagaimana mengembangkan minat dan bakat anak muda di desa Tuncung. Dalam perencanaan program kerja hasil dari observasi kemudian di organizing melalui diskusi dalam rapat posko desa tucung sebagai solusi untuk mengembangkan bakat anak muda desa melalui program kerja pengaktifan lembaga karang taruna.

Sosialisasi yang di lakukan itu berbentuk non fisik atau melalui rapat sebagai salah satu solusi untuk mengaktifkn lembaga karang taruna didesa tucung sebagai wadah bagi anak muda desa Tuncung dalam menuangkan bakatnya. Proses program kerja di lakukan di suatu wadah untuk mempertemukan Ketua karang taruna kecamatan maiwa dalam hal ini bapak haruna dengan masyrakat desa Tuncung. Sebagai rancangan untuk efesiensi waktu dalam sosialisasi tersebut, maka mahsiswa KKLP Posko tucung mengambil suatu metode dengan cara rapat secara langsung di dalam suatu tempat atau wadah yang di tentukan.

Pelaksanaan kegiatan yang di lakukan melalui rapat pengaktifan lembaga karang taruna ini kami bermitra dengan pihak Ketua karang taruna kecamatan maiwa dalam hal ini bapak haruna untuk memberikan pemahaman dan menambah wawasan mengenai metode meningkatkan dan mengembangkan bakat anak muda desa Tuncung melalui rapat pengaktifan lembaga karang taruna dari Ketua karang taruna kecamatan maiwa dan masyarakat yang menjadi peserta dalam sosialisasi tersebut dari anak muda desa Tuncung, dimana materi yang di sampaikan menjadi motivasi untuk meningkatkan bakat dan minat anak muda desa Tuncung

Di dalam hal ini hasil pelaksanaan sosialisasi yang telah di lakukan oleh mahasiwadandosenpendampingbermitra dengan pihak ketua karang taruna desa Tuncung sesuai dengan apa yang diharapkan pada perencanaan sebelumnya, dimana perencanaan yang diinginkan agar anak muda desa Tuncung memliki wadah dan tempat untuk menyalurkan aspirasi dan bakat mereka. Sebagai hasil program ini masyarakat sangat merespon peluang yang telah kami programkan, sebagaimna harapan kami anak muda desa Tuncung dapat mengembangkan bakat mereka melalui lembaga karang taruna yang telah di bentuk dalam rapat bersama di kantor desaTuncung.

\section{Bantuan Peralatan}

Dalam pelaksanaan kegiatan ini, kami menggunakan beberapa alat sebagai pelengkapan jalannya kegiatan atau mendukung kegiatan kegiatan untuk mencapai hasil yang maksimal. Beberapa alat yang kami gunakan yaitu:

1. Laptop

2. Infokus/LCD

3. White Board

4. Spidol 


\section{Indikator Keberhasilan}

Ukuran yang digunakan untuk mengetahui keberhasilan dari program ini adalah pengukuran tingkat pemahaman masyarakat tentang cara berorganisasi yang baik, struktur organisasi, pembentukan visi misi organisasi, serta pengaktifan kembali dan terbentuknya struktur organisasi Karang Taruna desa Tuncung. Kegiatan pengukuran dilakukan melalui wawacara atau tanya-jawab kepada masyarakat dan anggota organisasi Karang Taruna yang terpilih tentang tujuan dan fungsi dari Karang Taruna. Indikator keberhasilan yang lebih lazim dilakukan pada program ini yaitu melihat keaktifan dan keberlanjutan Karang Taruna di Desa Tuncung.

\section{Evaluasi Kegiatan}

Evaluasi dilakukan dalam program ini terlaksana secara sistematis sebagai berikut:

1. Evaluasi Perencanaan (Proposal)

2. Evaluasi Organisasi (Kerjasama)

3. Evaluasi Pelaksanaan (Implementasi Program)

4. Evaluasi Output (hasil Program)

5. Evaluasi Outcame (Dampak positf yang dapat dinikmati oleh masyarakat dan pengurus Karang Taruna).

\section{Keberlanjutan Dari Program Pengabdian Yang Dilaksanakan}

Adapun tindak lanjut yang diharapkan dari program ini yaitu:

1. Pendalaman kembali tentang tujuan dan fungsi Karang Taruna

2. Keterlibatan Karang Taruna dalam meningkatkan minat dan bakat remaja di Desa Tuncung

3. Keterlibatan Karang Taruna dalam setiap kegiatan yang diadakan masyarakat.

\section{Hambatan-Hambatan Yang Dihadapi Di Lapangan}

Hambatan-hambatan yang dihadapi dalam program ini yaitu:

1. Kurangnya motivasi masyarakat untuk mengelola Karang Taruna

2. Sulitnya membangun kepercayaan diri para anak muda / remaja Desa Tuncung untuk lebih aktif berperan di kegiatan masyarakat.

3. Terbatasnya pengetahuan masyakata tentang tujuan dan fungsi Karang Taruna

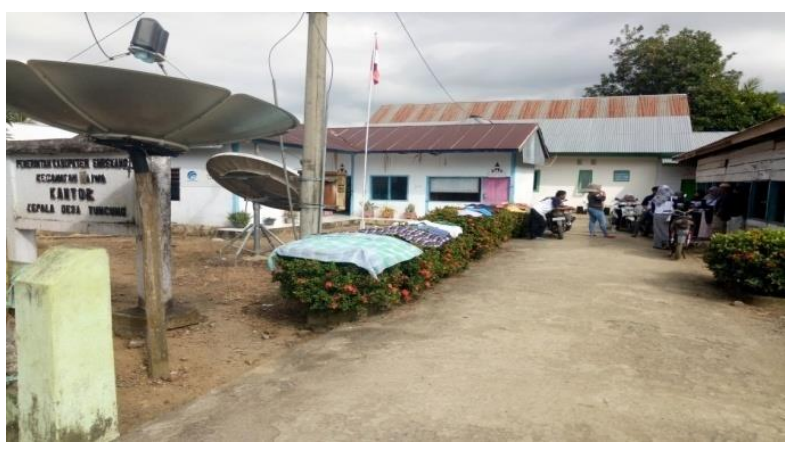

Gambar 1. Kantor DesaTuncung

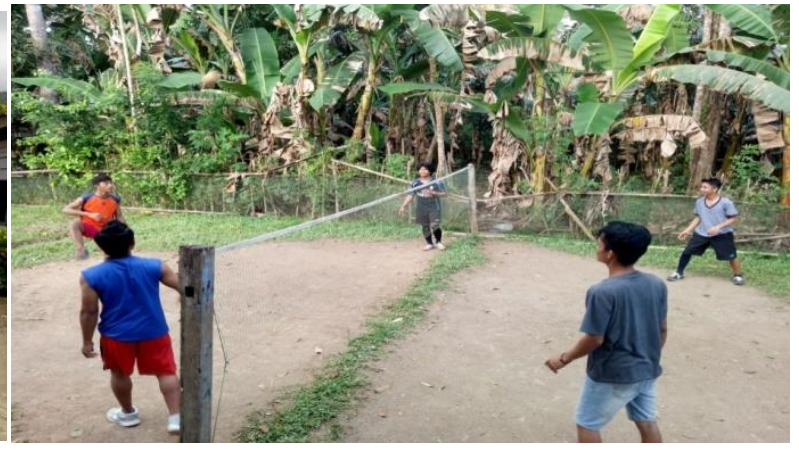

Gambar 2.Kegiatan karang taruna Desa Tuncung

\section{Simpulan Dan Saran}

Karang Taruna adalah suatu organisasi sosial, perkumpulan sosial yang dibentuk oleh masyarakat yang berfungsi sebagai sarana partisipasi masyarakat dalam melaksanakan Usaha Kesejahteraan Sosial (UKS).Sebagai wadah pengembangan generasi muda, Karang Taruna merupakan tempat diselenggarakannya berbagai upaya atau kegiatan untuk meningkatkan dan mengembangkan cipta, rasa, karsa, dan karya generasi muda dalam rangka pengembangan sumber daya manusia (SDM). 
Karang Taruna tumbuh dan berkembang atas dasar adanya kesadaran terhadap keadaan dan permasalahan di lingkungannya serta adanya tanggung jawab sosial untuk turut berusaha menanganinya. Kesadaran dan tanggung jawab sosial tersebut merupakan modal dasar tumbuh dan berkembangnya Karang Taruna. Organisasi Karang Taruna desa Tuncung diharapkan diaktifkan kembali agar pemuda-pemudi di DesaTuncung dapat mengambil bagian dalam pembangunan DesaTuncung.

\section{Daftar Rujukan}

Adi Fahrudin, 2011.Pemberdayaan Partisipasi \& Penguatan Kapasitas Masyarakat. Bandung.

Arif, dkk.2014. Peran Karang Taruna dalam Pembinaan Remaja di Dusun Candi Desa Candinegoro Kecamatan Wonoayu Kabupaten Sidoarjo. Kajian Moral dan Kewarganegaraan, Vol.1 No.2.

Astono, Juli, dkk. 2014. Pemberdayaan Karang Taruna dengan Keterampilan Las Kaca-Listrik untuk Pengembangan Wirausaha Kerajinan Kaca-Logam, Inotek, Vol.18,No.2.

Kadarisman, M. 2013. Manajemen Pengembangan Sumber Daya Manusia. PT. Raja GrafindoPersada. Jakarta.

Notoatmodjo, Soekidjo. 1998. PengembanganSumberDayaManusia. RinekaCipta. Jakarta. 